\title{
Effect of Addition of Rosemary Leaves Powder on the Rheological Characteristics of Dough in Addition to the Quality Attributes of Bread Manufactured from to Local Wheat.
}

\author{
Shetti,Saad.H \\ Al Hamza Agricultural preparatory. Dep. Vocational Education- Babil \\ Altae, Abd Ali.A \\ College of food science, Al.Qasim Green University \\ a_kutad673@Yahoo.com
}

ARTICLE INFO

Submission date: $18 / 7 / 2018$

Acceptance date: $2 / 10 / 2018$

Publication date: $10 / 3 / 2019$

\begin{abstract}
Different percentages $(2.5 \%, 5 \%$ and $7.5 \%)$ of rosemary leaves powder were added to local wheat flour( $80 \%$ extraction), to study the result of adding this herb on the rheological properties of dough. To reach this target, Farinograph was used to study the water absorption, dough development time, dough stability and degree of dough softening, the out come was compared with local wheat flour with out addition. The obtained results showed that local wheat had values of water absorption, dough stability approximate to those of the local wheat flour after adding the percent of 2.5 and $5 \%$ of degree dough softening from rosemary leaves powder. The water absorption, dough development time of local wheat flour was improved as a function of adding rosemary to the flour. The increase rosemary is forming, which helped include The water absorption, dough development time of local wheat flour. It can be concluded that rosemary leaves powder was able to improve the rheological properties of local wheat flour at $(2.5 \%$ and $5 \%)$ and a good quality loaf.
\end{abstract}

Keywords: rosemary, bread, local wheat, rheological.

\section{Introduction}

One ward of people all over the world have improved in the latter century unpaid to rise incoming, improved leisure time and reduced physical activity. The new life style has substantial impact on health[1].Now, foods are not intended to only satisfy hunger and provide necessary nutrients for humans but, also to prevent nutritionrelated diseases and increase physical and mental well-being of the consumers. In relation to this field, basic foods have an important role[2].

Bread is the main source food meeting nutritional needs of humans in the world. Bread supplies a significant portion of the nutrients required for growth and maintenance of health. In addition, it is one of the sources of proteins, vitamins, minerals, fibre and complex carbohydrates [3]. The rosemary plant can give electrons to the free radicals and thus the roots converted more balanced so that the rosemary gives protection to biological molecules such as proteins, sugars, fatty acids and amino acids, which has the ability to remove different types of active oxygen roots and other free radicals [4].The rosemary is one of the evergreen aromatic plants that 
belongs to the oral family and is increasingly used in food and has many medicinal benefits[5]. Rosemary consisted of dried leaves and flowers constitutes a particularly interesting basis of biologically active phytochemicals as it contains a variety of phenolic compounds containing carnosol, carnosic acid, rosmanol, 7-methylepirosmanol, isorosmanol, rosmadial and caffeic acid, with substantial in vitro antioxidant activity[6], [7].

Rosemary is one of the most widely commercialized plant extracts; it is reported to have antioxidant activity, it is also used as a culinary herb for flavoring and as an antioxidant in processed foods and cosmetics [8].Rosemary has some antioxidant phenolics that have been shown to supply a defense against oxidative stress from oxidizing managers and free radicals[9].A wealth of studies of rosemary plant demonstrated antioxidant, diuretic, anti inflammatory, anti-microbial, anticarcinogenic, hypoglycemic and hypolipidimic activities of rosemary[10], [11].

\section{The Aim of Study}

Improve the rheological properties of local wheat dough and the possibility of using factory bread to treat some chronic diseases.

\section{Material and Methods \\ Materials}

Wheat flour local (80\% extraction), rosemary (Rosmarinus officinalis L), yeast (Saccharomyces cerevisiae) Turkish-made type saf-instant., salt and sugar were obtained from a local market, Babil City, Iraq.

\section{Methods \\ Bread preparation}

Bread formulas were processed according to standard No.677.Iraqi year 1983. Formulas of wheat flour with rosemary leaves powder (Table 1) were prepared by mixing, rosemary leaves powder. 2.5, 5 and 7.5\%.The ingredients such as local wheat flour, yeast, salt and sugar revealed in Table (1) were mixed together manually to obtain uniform dough and dough was made to ferment for 30 minutes at room temperature $\left(25 \pm 2{ }^{\circ} \mathrm{C}\right)$, divided dough was allowable to relax for 10 minutes before divicly into pieces. The fermented pieces were shaped to the final form and fermented for additional 30 minutes $(25 \pm 2 \stackrel{\circ}{\mathrm{c}})$ and baked in an oven at $235^{\circ} \mathrm{c}$ for $2-5$ minutes, then keep it to cool at room temperature and kept in polyethylene bags at room temperature until used. 
Table (1): Formula of bread prepared using different herb

\begin{tabular}{|c|c|c|c|c|}
\hline \multirow{2}{*}{ Ingredients $\%$} & \multirow{3}{*}{ Control } & \multicolumn{3}{|c|}{ Replacement level } \\
\cline { 3 - 5 } & & $2.5 \%$ & $5 \%$ & $7.5 \%$ \\
\hline Wheat Flour & 97.5 & 95 & 92.5 & 90 \\
\hline Yeast & 1 & 1 & 1 & 1 \\
\hline Sugar & 0.5 & 0.5 & 0.5 & 0.5 \\
\hline Salt & 1 & 1 & 1 & 1 \\
\hline Rosemary & - & 2.5 & 5 & 7.5 \\
\hline
\end{tabular}

\section{Rheological measurements of dough formulas:}

\section{Farinograph test}

Farinograph parameters, namely water absorption, arrival time, dough development time, dough stability and weakening values of the dough were determined using the farinograph Model (Brabender Farinograph Germany HZ 50) at Babylon Government Mill according to[12].

\section{Sensory evaluation of bread}

Bread samples were appraised sensory assessment, by well panellists from College of food science, Al.Qasim Green University according to the method described by[13].for face color(20), back color (10), homogeneity of color (10), rubber and portability munching (10), odor (20), taste (20), steady shape (5), the fraction of edges (5).

\section{Analytical Methods}

\section{Gross chemical composition}

Protein, fat, crude fibers and ash contents of rosemary and bread was determined according to[14]. While carbohydrates percentage was designed by difference : carbohydrates $=100-[\%$ protein $+\%$ fat $+\%$ ash $+\%$ crude fiber $]$.

\section{Statistical analysis}

Data were ststistically analyzed according to the technique of analysis variance (ANOVA), the least significant difference (L.S.D) and Duncan's methods was used to compare the deference between the means of treatment values to the methods described by [15]. 


\section{Results and Discussion}

\section{Gross chemical composition of rosemary powder :}

Gross chemical compositions of rosemary leaves powder was determined and the results are presented in Table (2).

Table (2): Chemical composition of rosemary powder (on dry weight)

\begin{tabular}{|l|c|c|c|c|c|}
\hline Samples & Protein\% & Fat\% & Fiber\% & Ash\% & $\begin{array}{c}\text { Total } \\
\text { carbohydrate } \%\end{array}$ \\
\hline Rosemary & 6 & 20 & 35 & 7.96 & 31.04 \\
\hline
\end{tabular}

It is clear that protein content was $6 \%$ for rosemary leaves powder. the results show that the herb contains considerable amounts of fibre $35 \%$, also show that the fat content was higher in rosemary leaves powder $20 \%$ while the ash quantity was $7.96 \%$ .These results are in accordance with those of [16].

\section{Rheological measurements of dough formulas:}

\section{Farinograph test of bread samples:}

Farinograph test is one of tests achieved on the flour and give fallouts and information about the amount of water absorbed by flour, arrival time, development time of dough, stability of dough, quality of flour and its suitability for production of bread.Table (3) declares some qualitative indicators which were obtained from farinograph test. Table (3) presents the percentage of water absorption which is the amount of water at degree $31^{\circ} \mathrm{C}$ needed by the flour to get developed and strength dough, consisting of up to (500 B U) to four samples of flour extract $80 \%$ (A, A1, A2, A3).

The table presents that control sample (A) reached the high water absorption compared with other samples, (58.2\%).The sample (A3) showed lowest value of water absorption, $(56.7 \%)$. It has been observed that there is a gradual decrease in the absorption of water likened with control which may be due to reduction in the proportion of protein in the other samples.

Increasing the water absorption rates by the flour is due to many factors, counting increasing the ratio of flour extraction and increasing the ratio of protein [17].Development time of dough, which is a time in minutes beginning from adding water to flour until arrival time of the dough to the desired consistency at the highest point in farinograph curve, at $(500 \mathrm{BU})$, when the gluten network evolution integrated [18].

Data indicate that there is an increase in the development value of the sample A3, reaching (2 minutes). The increased dough development time and dough stability caused by supplementary herb contains a high percentage of fibre was possibly associated with slowed water hydration rate and dough development due to increased fiber content[19]. 
The results indicate that period needed for the samples A and A1 was equal, at (1 minute), and to samplesA2 (1.5 minutes). This table shows that arrival time dough which is a time required in minutes of add water to the flour until the arrival of the strength of the dough to $500 \mathrm{BU}$, of the samples $\mathrm{A}, \mathrm{A} 1$ and $\mathrm{A} 2$ equal, at $(0,5)$ minutes, while samples A3 was (1.0) minute.In relation to the dough stability times, which is the length of time (in minutes) from the starting of the arrival of the strength dough to the line $500 \mathrm{BU}$ until leaving this line. The samples A2 and A3 were the highest $(12,12.5)$ minutes, respectively shadowed by $\mathrm{A} 1$, was 10.5 minutes. While sample B time of stability was 9.5 minutes.

Table (3) demonstrates increasing the softening degree of dough sample A, at (100) BU, comparing with the sample (A1), which reached (40) BU, followed by A2, at (20) BU.While sample A3 which does not have a degree of softening that due to the rise in stability of dough up to $12 \%$, and which may in relation to a rich in total phenolic compounds and antioxidant activity. These results are agreed with [20], which fxited that the adding of phenols and antioxidants flour lead to changes in the mechanics of different interactive and dynamic interaction between the dough components of proteins, sugars, fiber and antioxidants, and which has changes in the dough, viscosity and behavior characteristics.

Table (3): Farinograph test of bread samples

\begin{tabular}{|c|c|c|c|c|c|c|}
\hline & & & Test & results of Farin & graph & \\
\hline & Samples & Water & Arrival time & Dough & Stability & Degree of \\
\hline $\mathbf{A}$ & $100 \%$ local wheat flour & 58.2 & 0.5 & 1.3 & 9.5 & 100 \\
\hline A1 & $\begin{array}{l}100 \% \text { local wheat flour } \\
+2.5 \% \text { rosemary }\end{array}$ & 57.3 & 0.5 & 1.3 & 10.5 & 20 \\
\hline A2 & $\begin{array}{l}100 \% \text { local wheat } \\
\text { flour+5\% rosemary }\end{array}$ & 57.3 & 0.5 & 1.5 & 12 & 40 \\
\hline A3 & $\begin{array}{l}100 \% \text { local wheat flour } \\
+7.5 \% \text { rosemary }\end{array}$ & 56.7 & 1.0 & 2.0 & 12.5 & $--(\mathrm{N} \mathrm{D})^{*}$ \\
\hline
\end{tabular}

N D* $=$ Not detected

\section{Chemical composition of bread samples:-}

Data in Table (4) display that the moisture content of bread was significantly affected by the addition of herb the highset content of moisture $(8.34 \%)$ was detected in rosemary bread (5\%). Fat of different bread treatment were nearly,the highest fat content was observed in rosemary bread $(2.5 \%)$. Upshots of protein content (Table 4) indicate that bread made from local wheat flour only had the highest content 
(14.60\%) followed by $2.5 \%$ rosemary bread (14.33\%). The ash content of bread was differed significantly according the additive. The highest ash content was observed in rosemary bread $(7.5 \%)$ [21].

Table ( 4 ) Chemical composition of bread samples (\% dry weight).

\begin{tabular}{|l|c|c|c|c|c|c|}
\hline \multicolumn{1}{|c|}{ Constituents } & Moisture & Fat & Protein & Fiber & Ash & $\begin{array}{c}\text { Total } \\
\text { carbohy }\end{array}$ \\
\hline $\begin{array}{l}\text { A 100\% local wheat } \\
\text { flour }\end{array}$ & 7.80 & 4.55 & 14.60 & 1.12 & 0.61 & 78.06 \\
\hline $\begin{array}{l}\text { A1 } \mathbf{1 0 0 \%} \text { local wheat } \\
\text { flour +2.5\% rosemary }\end{array}$ & 7.80 & 5.67 & 14.33 & 1.82 & 0.68 & 77.56 \\
\hline $\begin{array}{l}\text { A2 } \mathbf{1 0 0 \%} \text { local wheat } \\
\text { flour +5\% rosemary }\end{array}$ & 8.34 & 5.43 & 14.19 & 1.78 & 0.80 & 77.12 \\
\hline $\begin{array}{l}\text { A3 } \mathbf{1 0 0 \%} \text { local wheat } \\
\text { flour +7.5\% rosemary }\end{array}$ & 7.55 & 5.30 & 13.84 & 1.55 & 1.05 & 76.81 \\
\hline
\end{tabular}

\section{Sensory evaluation of bread samples:}

Sensory assessment of bread samples was illustrated in Table (5). The results declare that control bread sample recorded the highest score (88.50) compared with other bread samples.

Bread sample consisting rosemary had got the highest overall acceptability $(86.38 \%)$ at a level $2.5 \%$. followed by rosemary bread $(82.80 \%)$ at a level $5 \%$ while rosemary bread(7.5\%) recorded $62.30 \%$. From data in Table (5), it can be seen that increasing the level of added herb reduced overall acceptability of bread. The addition of herb to bread improved the odor and color compared with control. Rosemary bread (2.5\%) got the highest recorded for face color (17.68). This may be attributed to the higher content of volatile aromatic or essential compounds and oils rosemary. On the other side addition of rosemary at $7.5 \%$ reduced all sensory attributes relative to other herb. For that reason, the bread sample containing $7.5 \%$ of herb was excepted according to their low overall acceptability. Generally, it could be experiential that the addition of selected plant to bread did not affect greatly on sensory properties [22],[23].

[24], establish through sensory assessment that consumer panellists judged these fibre-enriched breads as acceptable. Therefore, the use of these herbs, especially rosemary $2.5 \%$, allows an upsurge of the daily intake of herbs without promoting negative effects on the rheological properties of doughs or quality and overall acceptability of the resulting bread. 
Table (5): Sensory evaluation of bread samples.

\begin{tabular}{|c|c|c|c|c|c|c|c|c|c|}
\hline $\begin{array}{r}\text { Charact } \\
\text { ers }\end{array}$ & 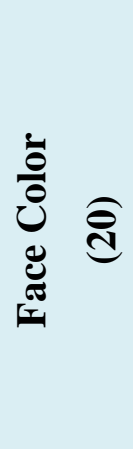 & 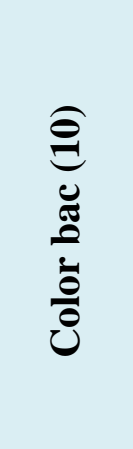 & 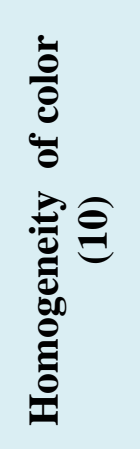 & 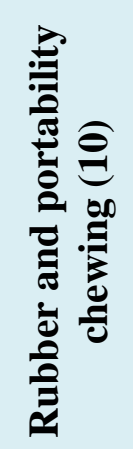 & $\begin{array}{c}\text { đิ } \\
\stackrel{0}{0} \\
0\end{array}$ & 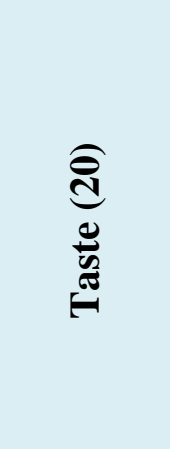 & 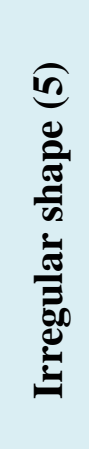 & 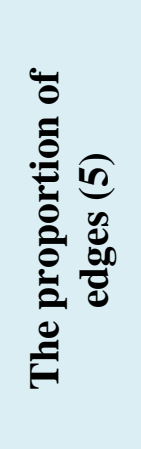 & $\stackrel{\text { సే }}{\stackrel{\theta}{\Theta}}$ \\
\hline $\mathbf{A}$ & $\begin{array}{c}17.70 \\
\mathrm{a}\end{array}$ & $9.10 \mathrm{a}$ & $8.50 \mathrm{a}$ & $8.40 \mathrm{a}$ & $\begin{array}{c}18.00 \\
a\end{array}$ & 17.90 a & $\begin{array}{c}4.70 \\
a\end{array}$ & $\begin{array}{c}4.20 \\
a b\end{array}$ & $\begin{array}{c}\mathbf{8 8 . 5 0} \\
\mathbf{a}\end{array}$ \\
\hline A1 & $\begin{array}{c}17.67 \\
\mathrm{a}\end{array}$ & $\begin{array}{c}7.80 \\
\text { ab }\end{array}$ & $\begin{array}{c}7.90 \\
\text { ab }\end{array}$ & 8.30 a & $\begin{array}{c}17.40 \\
\text { ab }\end{array}$ & 18.10 a & $\begin{array}{c}4.50 \\
\text { ab }\end{array}$ & $4.70 \mathrm{a}$ & $\begin{array}{c}86.37 \\
\text { ab }\end{array}$ \\
\hline A2 & $\begin{array}{c}17.61 \\
\mathrm{a}\end{array}$ & $\begin{array}{c}7.69 \\
\text { ab }\end{array}$ & $\begin{array}{c}7.30 \\
\text { ab }\end{array}$ & $\begin{array}{l}7.60 \\
\text { ab }\end{array}$ & $\begin{array}{c}17.21 \\
\text { ab }\end{array}$ & $\begin{array}{c}16.90 \\
\text { ab }\end{array}$ & $\begin{array}{c}4.30 \\
\text { ab }\end{array}$ & $\begin{array}{c}4.20 \\
\mathrm{ab}\end{array}$ & $\begin{array}{c}82.81 \\
\text { abc }\end{array}$ \\
\hline A3 & $\begin{array}{c}13.41 \\
\text { bc }\end{array}$ & $6.10 \mathrm{~b}$ & $\begin{array}{c}5.41 \\
\text { ab }\end{array}$ & $\begin{array}{c}5.60 \\
\text { ab }\end{array}$ & $\begin{array}{c}13.70 \\
\text { cd }\end{array}$ & $13.11 \mathrm{~cd}$ & $\begin{array}{c}3.10 \\
\text { ab }\end{array}$ & $1.90 \mathrm{~b}$ & $\begin{array}{c}62.33 \\
\text { de }\end{array}$ \\
\hline
\end{tabular}

LSD $\leq 0.05$

$\mathrm{A}=$ Bread $100 \%$ wheat flour, $\mathrm{A} 1=$ bread $2.5 \%$ rosemary, $\mathrm{A} 2=$ bread $5 \%$ rosemary,

A3 $=$ bread $7.5 \%$ rosemary

\section{CONFLICT OF INTERESTS.}

There are non-conflicts of interest.

\section{References}

[1] B.V. Venugopal, "Functional foods: an overview, marine wourld "J of $D$ and Sci, 7(1) : 01-20. (2009).

[2] A. A. Hassan, N. M.Rasmy, M. I. Foda, and W. K. Bahgaat, "Production of functional biscuits for lowering blood lipids". World J of Dairy \& Food Sci 7 (1): 01-20. (2012).

[3] M. H. Azizi and G.V. Rao, "Effect of storage of surfactant gels on bread making quality of wheat flour". Food Chem., 89: 133-138( 2005).

[4] A.S. Saber, and A.L. Hawazen, "Protective Effect of Rosemary (Rosmarinus officinalis) Leaves Extract on Carbon Tetrachloride-Induced Nephrotoxicity in Albino Rats". Life Science Journal, 9, 779-785. (2012)

[5] A. M. Ibrahim, M.M. Abdel and A. E. Abd Al- Moneim,"Evaluation of the efficacy of the water and zythe extract of the rosemary plant in the Inhibition of certain organisms Pathological Microbiology" J of Irq Vet.M,V33,2,.34-20. (2009).

[6] K.S. El Deeb, "Investigation of Tannin in Some Labiatae Species". Bulletin of Faculty of Pharmacy, 31, 237-241. (1993).

[7] M. Herrero, M.Plaza, A. Cifuentes, and E. Ibanez, "Green Processes for the Extraction of Bioactives from Rosemary: Chemical and Functional 
Characterization via Ultra-Performance Liquid Chromatography-Tandem Mass Spectrometry and in-Vitro Assays". J of Ch, 1217, 2512-2520. (2010)

[8] W. Zheng and S.Y. Wang, "Antioxidant Activity and Phenolic Compounds in Selected Herbs". Journal of Agri and Food Chem, 49, 5165-5170. (2001).

[9] A.Matkowski,"Plant Phenolic Metabolites as Antioxidantsand Antimutagens. In:Blume", V. 376,IOS Press, Amsterdam, 129-148. (2006).

[10] R.P. Dearlove, P.Greenspan, D.K.Hartle, R.B. Swanson, and J.L. Hargrove, "Inhibition of Protein Glycationby Extracts of Culinary Herbs and Spices". Journal of Medicinal Food, 11, 275-281. (2008).

[11] T.Nabekura, T.Yamaki, T.Hiroi, K. Ueno and S. Kitagawa, "Inhibition of Anticancer Drug Efflux Transporter P-Glycoprotein by Rosemary Phytochemicals". Pharmacological Research, 61, 259-263. (2010).

[12] A.A.C.C. "Official Method of Analysis. (16 ${ }^{\text {th }}$ End) Association of Official Analytical Chemists Washington" DC, USA.PP. (2007).

[13] A.W.Jaber, "Study to install the quality of raw materials and manufacturing methods and help to improve.Iraqi production of bread (Alsamun)" M.S. Agri. Uni of Baghdad Dep.f. I. ,(1981).

[14] A.O.A.C. "Official method of analysis, Association of officinal Analytical chemists", $15^{\text {th }}$ ed. Washington, D.C., USA.PP. (1990).

[15] K.A. Gomez, and A.A. Gomez , "Statistical Procedures for Agricultural Research”. 2nd Ed., Jhon Wiley and Sons Inc., New York, pp: 95-109. (1984).

[16] F.A.Lahlou, F. Hmimid, M. Loutfi and N. Bourhim, "Rosmarinus officinalis fresh leaves nutritive value per $100 \mathrm{~g}$, source usda national nutriet data base" (2012).

[17] Y.Pomeranz, Z.Czuchajowska, M. D.Shogren, G.L.Rubenthaler, L.C.Bolte, H.C. Jeffers and p.j.Mattern, "Hardness and functional (bread and cookie- making) properties of U.S.wheats". Cereal Foods World 33 : 297,(1988).

[18] A.H. Bloksma, "Rheology of the bread making process". Cereal Foods World 35(2), 228-236, 959-960.compounds from the ocean, CRC Press, Boca Raton, pp. 1-22. (1990).

[19] M.L.Sudha, R.Vetrimani, and K.Leelavathi, "Influence of fibre from different cereals on the rheological characteristics of wheat flour dough and on biscuit quality". Food Chem 100:1365-1370 . (2007).

[20] S.Sivam, S.W.Dongxiao, Y. Q. Siew, and O. Conrad, "Properties of Bread Dough with Added Fiber Polysaccharides and Phenolic Antioxidants". J.of Food Sci V. 75, Nr. 8 . (2010).

[21] A.M.S.Hussein, M.S.Shaheen, H.H. Abdel-Kalek, and S.A.H. Abo Elnoor, Production of low calorie bakery product with pleasant flavour,antioxidant and antimicrobial activities. Pol. J. Food N. Sci., 64(4): 253-265. (2014).

[22] A.M.Khorshid, H.A. A. Nadia, and J.S. Fahim, "Utilization of flaxseeds in improving bread quality".Egypt. J. Agric. Res., 89(1): 241-250. (2011).

[23] A. M.Basuny, S L.Nasef, A.M. Mahmoud and M.A.Shaker, "Use of medicinal and aromatic plants for increasing quality of some bakery products". Int. Sci. Invest. J., 54, 820-828. (2012).

[24] W. Jinshui, M .R.Cristina and C. Barber, "Effect of the addition of different fibres on wheat dough performance and bread quality". J: Food Chemistry vol. 79, no. 2, pp. 221-226. (2002). 


\section{الخلاصة}

أضيفت تراكيز مختلفة من مسحوق نبات اكليل بنسب (2,5\% و 5\% و 7,5\%) إلى دقيق الحنطة المحلية (استخلاص

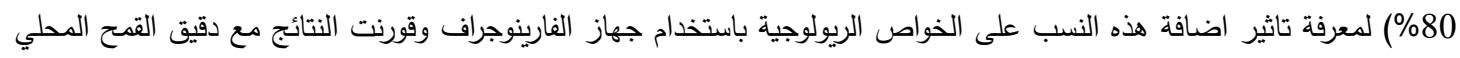

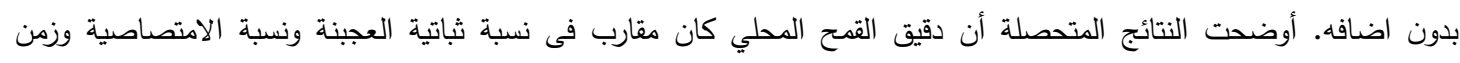

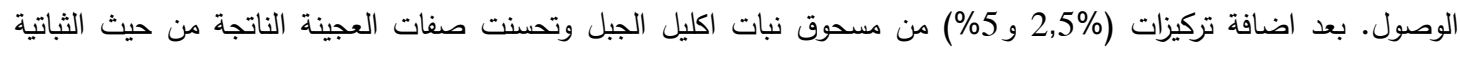

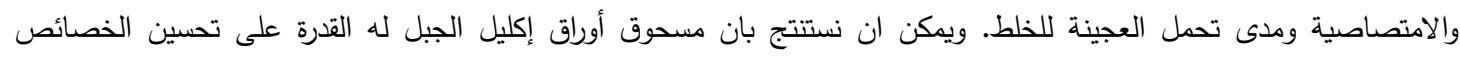
الريولوجية لطحين القحح المحلي عند (2.5 5 5\%) والى رغيف ذو مواصفات جيده. 